\title{
Ingrid Wotschke*
}

\section{Estuary English: a case of sociophonetic convergence}

\begin{abstract}
Coined by David Rosewarne in 1984, the term "Estuary English" describes the trendy usage of the younger generations in the South-East of England, socially ranging from the upwardly mobile to the traditionally educated and linguistically situated in the "middle ground”, between Cockney and RP. Sociophonetic convergence not only characterizes the variant's South-of-London origin and its geographical spread to the North but also determines its social functions and accounts for different judgements on its current role and future prospects.
\end{abstract}

\section{Origins and conceptions}

Coining the term together with his article in The Times Educational Supplement of 19 October 1984, David Rosewarne described the banks of the Thames and its Estuary as the heartland of the new variant which, beyond its original borders, seemed to be "the most influential accent in the south-east of England” (p. 29). The source of origin of what was labelled "Estuary English" may be seen in the post-War uprooting and transplanting of large numbers of Cockney speakers to municipal housing sites in the Home Counties, following the blitz ${ }^{1}$, and in the move of considerable numbers of London elderly to the coasts of Sussex, Kent and East Anglia between the fifties and the seventies (cf. Coggle 1993: 24; Rosewarne 1994: 4). By the mid-nineties, however, the results of an extraordinary geographical spread had made the term Estuary English “something of a misnomer” (Crystal 1995: 327; cf. Maidment 1994: 6)

1 Once widespread for German airrades on British cities in World War II (cf. "blitz attacks”, Longman Dictionary of English Language and Culture 1992: 118).

\footnotetext{
* Ingrid Wotschke

Leipziger Str. 68

D-39112 Magdeburg
}

Hermes - Journal of Language and Communication Studies no 38-2007 
for a variant which was not only extending into Essex and Kent in the South East and on to the coast, but also to the Oxford-Cambridge-London triangle and from there further northwards and westwards to Norwich and Cornwall and could be heard along three other estuaries - of the Humber in the North East, the Dee in the North West and the Severn in the West (cf. Rosewarne 1994: 4; Crystal ibid.). The extension of the variant beyond the borders of the South East was considered to have been furthered and enhanced by the mobility of the time, with people commuting for work and moving to "new towns" everywhere in the country as well as by the influence of the media exhibiting fashionably cockneyfied speech in entertainment programmes and advertisements and in the speech of personalities, so that the accent was considered to be gaining ground through the same channels as RP had done in its spread earlier in the past century (cf. Rosewarne ibid. 7; Crystal ibid.).

Although Estuary characteristics have so far not been found among BBC news presenters and commentators, they were nevertheless to be heard in other parts of the programme, with far-reaching assimilation in question ['kwe $\int \mathrm{t} \int \mathrm{n}$ ] and T-glottalling in what's [wD?s] more in a light music broadcast even on the traditionally prestigious BBC World Service (11/11/2001). The considerable amount of trendy features in all kinds of programmes on (Independent) Capital Radio London in cases as tube [t $\mathrm{fu}: \mathrm{b}]$ lines, team [ $\left.\mathrm{t}^{\mathrm{t}} \mathrm{\textrm {I }} \mathrm{\textrm {m }}\right]$ ] and haven't got ['hævy? 'gp? ] anything proves the variant's leading role in fashionable Southern speech (3/5/1995), while Birmingham tonight [tə'naI?] or you can get this ['ge? ðIs] in announcements and advertisements on (Independent) Hallam FM (Sheffield, 20/7/2000) stand for the much-quoted spread of originally southern T-glottalling to young speech in the North (cf. Wells 1982 pt.1: 261; Widdowson 1999 :13, et al.). In the youngest generation, the spread of Estuary English was considered to be particularly furthered by children's TV - "that brassy, relentless patter with its East End flavour" becoming "the voice in which the nation chats up its children" (Ascherson 1994: 1) - with the result that children in Milton Keynes were losing Buckinghamshire pronunciation and "melding their speech into uniform, Londonish sounds", saying “'ahm' for arm, 'naa-it' for night, and 'le'er' for letter” (cf. ibid.). A fundamental reason for the wide spread of the accent in the younger generations was seen by Maidment in changes in the social meaning of formality and informality and a resulting tendency to mix accents in this "post-mod- 
ern" age (cf. 1994: 6). So, then, why not call it "Post-Modern English" (ibid.) rather than "Estuary"?

Being the trendy usage of the younger generations in the South East based on the area of the Thames valley north and south of London (cf. Mugglestone 1995: 96), Estuary English has been widely considered to combine traditional South Eastern with fashionable London and RP characteristics in a "mixture of Received Pronunciation with Scarf London" (Forbes, The Express 5/6/98: 10). In his early definition, David Rosewarne had characterized his concept as a "variety of modified regional speech" being a mixture of non-regional and local south-eastern pronunciation and intonation within "a continuum with RP and London speech at either end", where speakers of Estuary English were grouped "in the middle ground" (cf. 1984: 29). His latter idea was taken up again in the confirmation of the role of Estuary English as a "sociolinguistic and geographical continuum between RP and Cockney" by Foulkes and Docherty (1999: 11), who regarded the neutral position of the accent representing "neither standard nor extreme non-standard poles" (ibid.) the reason for its further spread (cf. also "mainstream Estuary speakers”, Coggle 1993: 68). In 2001, Kerswill again described the approach of speakers to Estuary English as a process of accommodation either upwards or downwards to the "middle ground", with "both the higher and lower groups converging on this variety"(p. 6). Rosewarne's abovementioned qualification of the variant as "modified regional speech", however, was re-interpreted into "a type of Regional RP ... heavily influenced by Cockney" (Cruttenden 1994: 86), into "a levelled variety ... localized to the South East” (Watt/ Milroy 1999: 43), or simply into "London English" (cf. Wells 1994(3): 1), though it was obviously reaching much further than the Greater London area.

Socially speaking, due to its position in the "middle ground", the variant might be considered either "a middle-class pronunciation typical of the Thames Estuary” (Cruttenden 1994: 86) or "a 'classless' blend of RP and 'Cockney"” (Mugglestone 1995: 96). Being regarded as "the aspirant child of Cockney, having emigrated, like its users, from the terraces of the East End” by McKay (1996: 1), it was labelled "a bastardized version of Cockney" by some, and "its educated counterpart" by others (Wells 1998: 1). Historically, it was considered to be one of the accents that "originate in the lower classes" (Coggle 1994: 1) as "a marker of social identity" (Bex 1994: 1) and thus looked upon as a "par- 
ticular example of the resistance that dialects show against becoming fully standardized and homogenized" in "this new development away from RP” (Kerswill 2001: 6) - similar to early modern Cockney which once preserved the traditional London dialect in the face of the emerging prestige variant (cf. Smith 1969: 8). On the other hand, the spread of Estuary up north was regarded as a continuation of the historical process of standardization becoming more speedy and obvious under the conditions of modern social mobility - a continuation of the "long process by which London pronunciation made itself felt" (Rosewarne 1984: 1) or, with new emphasis on its popular element, of the centuries-long "tendency for features of popular London speech to spread out geographically (to other parts of the country) and socially (to higher social classes)" (Wells 1997: 2).

\section{Social implications}

The acquisition and spread of the successful variant in young people was traced by Rosewarne (1994: 7), with results reaffirming its socially complex origins and connotations. While secondary school students with local accent backgrounds were reported to adopt Estuary English rating it more "sophisticated" and even envisioning RP for their later age, those from an RP-speaking background were aiming at "street credibility" through more popular speech in order to "fit into the group" and "appear tough" (for girls and boys, rsp.; cf. ibid.). With regard to the linguistic results of the mixing of RP and non-RP children in comprehensive and public schools, Rosewarne (ibid.) pointed to large numbers of the comprehensive schools pupils in the Southern half of England leaving as Estuary speakers on grounds of effective peer group pressure exercised on those from RP-speaking families. A most interesting and revealing piece of writing illustrates the social role of Estuary English in the mind of a fifteen-year-old boy of The Kings School, Canterbury (presented in Schoenberger 2001: 3). In the boy's school essay, the accent appears as a "classless dialect", spoken by the Princess of Wales as well as by those wanting "to increase their 'coolness", among them some of the upper class who would like to sound "less posh and more cool", while some of the middle class would rather "prefer to have an upper-class accent”. Viewed from a decidedly democratic and cosmopolitan angle, the accent is ascribed to "whatever class, whatever re- 
gion (although at this moment it is mainly in the south) and whatever race", and people are considered "less conscious about what they sound like". Towards the end of this text, however, the young writer seems to be rather concerned about his own usage, admitting: “... every now and again, I miss out letters and also slur words. However, if need be I can speak very pronounced" (ibid.). After this, the existence of Estuary English as a discrete dialect or accent is leading to a particular kind of educated "bilingualism", at least so in the Southern half of England, similar to style shifting between regional accent and RP as is now common practice among the young generation of traditionally RP-speaking families in the North.

With its popular flavour, Estuary English became current usage among middle-class speakers and the upper-class young, both moving "downmarket" to avoid the "establishment connotations" of RP, particularly those of what was still considered "conservative" or "advanced" in Rosewarne's early time and later more generally called "posh" (cf. Rosewarne 1984: 3; Crystal 1995: 2)2. It was accepted and adopted by many of the young educated, among them young actors of the Royal Shakespeare Company (Morrish 1991: 1), and it was soon current among the academic staff across faculties and career structures, even including professors and deans (cf. Coggle 1993: 75). It further became well established in the Civil Service, the local government and the medical and teaching professions, it was to be heard in the House of Commons and in the Lords, and it was even ascribed to the Archbishop of Canterbury. In its relative closeness to the prestige accent, on the other hand, it was held to stand for lower-class upstarts striving to fit into their new environments by compromising linguistically - self-made young people, well-to-do and upwardly mobile as represented by the "yuppies" and "Essex man" in the media of the 1980s, correcting their speech and getting rid of the non-standard "defects" of double negatives and dialectal tense forms, avoiding stigmatized pronunciations in 'ouse (house) and now [æu] and replacing intervocal T-glottalling in wa'er (water) by prestigious /t/ (cf. Kerswill 2001: 6, 8). Suggesting efficiency and success, Estuary made its speakers be widely chosen for

2 Being “derogative for or typical of people of high social class" (ibid. 1024), "posh” became synonymous with a lifestyle exclusive as well as outdated and with a pronunciation marked by Upper-crust or conservative RP (cf. Morrish 1999:1). 
advertising as they were considered to appeal more successfully than speakers of RP to the large potential of newly-rich customers of non-exclusive social backgrounds, "because of their accents not despite them" (Coggle 1993: 78). Consequently, Kerswill saw in the variant "not ... a reflection of any greater democratic ideology in society, but a brutal result of new power bases (the newly-wealthy) replacing older ones" (ibid. 8), and an arriviste social position was simply referred to by "estuarian” in The Guardian in 1996 (cf. Wells 1997: 1) Being a vehicle of popular up-to-datedness and of professional egalitarianism - "They don' talk like they was differen', see ... makes us feel goo', don' i'?”- the accent was even considered to "smoothe away old class distinctions"(cf. Forbes, The Express 5/6/98: 10). The Express 5/6/98).With his conception of the widening social validity of the variant as "a linguistic reflection of the changes in class barriers in Britain" and, more definitely, as "a sign that class barriers g[were] coming down" in result of "the development of less exclusive linguistic networks in Britain" (1984: 1, 1994: 8), Rosewarne himself had laid the foundations for recent claims to the accent's correspondence with the new social atmosphere of gender equality, race relations and changing moral attitudes on issues like abortion, contraception and homosexuality (cf. Kerswill 2001: 6).

Irrespective of the social background and generation of its speakers, Estuary English has always been a compromise between social constraints and the individual identities of those who were, in Rosewarne's words, "rising, falling or maintaining their position socioeconomically" (1994: 7). As Estuary had become attractive to many - the democratic-minded and those who pretended to be, the lower (middle)-class upstarts and the frustrated upper middle-class shunning "posh" for its social disadvantages - social motivations for its application were manifold, though frequently determined by the aim to exploit the possibilities the variant might offer to disguise one's sociolinguistic identity in favour of a new and more favourable one. What was most significant was the ease with which top people adopted the accent which "obscure[d] sociolinguistic origins" (cf. Rosewarne 1984: 29), to an extent that made Maidment entitle his 1994 paper "Estuary English: Hybrid or Hype?”. So Estuary became current among business circles of the city - formerly the preserve of RP - in order to be more "consumer-friendly", and its fashionable attraction made it the "class-free" accent of stars, disc jockeys and sportsmen (cf. Rosewarne 1984: 29; 
1994: 4 f.; Coggle 1993: 77 ff.). Moreover, the variant might be considered an asset of politicians in the eighties and nineties, in a similar way as West country dialects had been in the seventies when Harold Wilson "talked more Yorkshire when he smoked his pipe in public than when he smoked cigars in private". (Forbes, The Express 5/6/98: 10). After Forbes, they soon discovered the possibility to "slip into it and out of" and were "switching voices to give themselves street cred", as Maggie Thatcher once did when speaking in the Commons (though, after Rosewarne 1994 p. 1, she never did), and Tony Blair now does when addressing a public meeting, "dropping his h's and letting consonants die in the air" (ibid.). Prince Edward, too, was claimed to be a speaker of Estuary English, and even the late Princess of Wales "increasingly allow[ed] a touch of Estuary into her voice" (ibid.), though the fashionable Londonisms in their speech might possibly be better ascribed to upper (middle)-class Sloane Ranger ${ }^{3}$. Hence, relying on the TV soap "East Enders", the accent might be placed just "between Cockney and the Queen (Rosewarne 1994:3).

\section{Linguistic features}

The realized variability of Estuary English as a modified and levelled variant has not only complicated its sociolinguistic demarcation in the "middle ground" but also its adequate linguistic description between Cockney and RP. Attempts have been made to make the phonetic task manageable by relating the accent's articulatory features to its two poles, with particular weight being placed on its Cockney features. The most obvious Cockneyisms considered to mark the accent off from RP were replacement of /t/ by glottal stop / $/$ /, medial and final as in state[?]ment and take it[?] off, as well as vocalization of /l/, mainly word-final or in final clusters, with various vowels mergers like $/ \mathrm{w} /, / \mathrm{u} /$ or $/ \mathrm{p} /$ in milk [w p] or bottle [u] (cf. Rosewarne 1984: 29; Coggle 1993: 29 ff.). And while, in the former case, RP speakers might tap the most t's and Cockney speakers the fewest, Estuary speakers might find themselves

3 Defined as "the voice of the London upwardly mobile (the 'Sloane Rangers') in the 1980s” by Crystal (1995:365), the term takes its first element from Sloane Square in the prestigious area of Kensington and combines it in a pun with the second element of American "Loan Ranger”, as used by masked Cowboy-resuming people (native-speaker informant). 
180

"in the middle range", tapping certain t's and dropping others (cf. Coggle ibid. $30 \mathrm{f}$.). In addition, Yod-coalescence (through assimilation) was found in Tuesday [tç] or Duke [d3], Yod-deletion in absolute and assume (Rosewarne 1984: 29; Wells 1997: 2). Cockney vowel characteristics were found to be diphthongization of $\mathrm{RP} / \mathrm{s}: /$ to nasal sounding [ $\mathrm{o}$ : $\mathrm{w}$ ] in awful, fronted [æ] in come, and lengthening and diphthongization of word-final vowels as in $\left.m e{ }^{{ }^{\ominus}} \mathrm{i}:\right]$ and city $\left[{ }^{\circ} \mathrm{I}:\right]$, beside further opening of RP /ov/ to Cockney [au] in no, and far-reaching diphthong-shift in the vowels of face [ar], price [pr] and goat [عu] (cf. Rosewarne ibid.; Coggle 1993: 29 ff.; Maidment 1994: 3). At the same time, Estuary English was considered to mark itself off from Cockney, mainly by exclusion of H-dropping in hand, of TH-fronting in think [f] and mother [v], of intervocal/P/ for /t/ in water, and of final G-dropping in ing-endings (cf. Crystal 1995: 2; Wells 1997: 2).

On a wider, more cosmopolitan level, characteristic Cockney features, such as Yod-deletion, T-glottalling and final G-dropping as well as certain realizations of glides, were reinforced through American and Australian influence on young speech and, with it, on the Estuary accent. So American influence may have finally made Cockney Yod-dropping in [su:t] (suit) the winner over [sju:t] and ['i:ðə] be preferred in either [агðə] by about one third of the youngest age group, (cf. Barber 1993: 272; Wells 1994 (1): 4). And even though American T-glottalling or -dropping, as heard from a former CIA chief branding that [?] kind of lavish lifestyle (Capital Radio London 3/5/95), or from the former President Bill Clinton pronouncing his name as Clin'n, may be considered of no special influence on the fashionable Cockney pronunciation in England (cf. Honey 1997: 248 f.), features like these will nevertheless have supported and strengthened these features among the young (influence of American usage see below). Further cockneyisms will have been reinforced by Australian pronunciation coming in with BBC television and exerting considerable influence on young speech over the last twenty years (personal information Widdowson et al.). In their historical closeness to London Cockney, (cf. McCrum et al. 1992: 317 f.), a number of these features were directly equivalent to the above-cited Estuary characteristics, among them the vowel glides in see [ $\left.\mathcal{\varepsilon}^{\prime} \mathrm{I}\right]$, why [эI] and every day [aI] as well as T-glottalling in a bit late [ə'bı? 'lai?] and put it ['pu? I?] in the corner (TV-series "Neighbours" 22/7/2003). 
Claims about distinct phonetic and phonological features of the accent were viewed with scepticism and the boundaries between Cockney and RP regarded as "extremely fuzzy" by J. A. Maidment (1994: 5), on grounds of style shifting and resulting overlaps of Cockney-like realizations which made the only features that were supposedly unique to the variant seem "very dubious", while the rest were found "in Cockney, or RP, or in some cases both" (cf. ibid.). The different patterns of exhibition and avoidance of $\mathrm{H}$-dropping and T-glottalling were referred to style shifting, based on the formality of the situation for speakers of both Estuary English and Cockney (ibid.), while special intonation characteristics, including prominence on prepositions and auxiliaries beside a characteristic rise/fall pattern and a narrower pitch range than in RP as considered typical by Rosewarne in 1984 (p. 2), were rejected on grounds of their occurrence in further English accents (cf. Maidment 1994: 41). Wells, however, connecting stylistic considerations with the question whether the new variant was to be regarded as a "dialect" or an "accent" in its own right (see below), or whether it was the formal style while Cockney was the informal one, concluded a linguistic distinctiveness of the accent from the existence of its phonetically nonstigmatized casual styles (without $\mathrm{H}$-dropping), and from the practical inability of Cockney speakers to use standard grammar (cf. 1994 (2): 1 f.). On these premises, he later proposed a definition pinning down Estuary as "standard English spoken with an accent that includes features localizable in the southeast of England" (1998: 1). In order to meet the particular requirements of a phonetic representation of the articulatory pattern, an attempt was made by Wells to fix a new standardized transcription especially for application to Estuary English (cf. 1994 (2): 1; 1994 (3): 1 ff.).

When, in the early nineties, the question was asked whether Estuary English might be regarded as an accent or a dialect, "a good deal of confusion about this” was criticized by Maidment (1994: 5), referring to the inclusion of non-articulatory features in Paul Coggle's book of 1993 and to an alleged lack of theoretical distinction between pronunciation, vocabulary and syntax in Rosewarne's descriptions of 1984 and 1994. Coggle (ibid. 34 f.) had mentioned certain grammatical features of Cockney and American English penetrating into the dialect, among them generalization of third person singular (We was away), a widened use of ain't in place of am not, is not, have not, etc. (I ain't well, She 
ain't it), double negation (I ain't got no money), and an extensive use of question tags (I've got problems, ain't I). He had further mentioned lexical items as hopefully, Right (for British English Correct or Certainly), and the widespread greeting $\mathrm{Hi}$ as some among the host of Americanisms intruding on British English through the cosmopolitan openness of the London-centred variant (cf. ibid. 59 ff.). Particular features of vocabulary had also been listed by Rosewarne (1994: 6), such as frequent use of basically, Cheers for Thank you and also for Good-bye, There you go for Here you are, beside further Americanisms such as Excuse me for Sorry, Busy for Engaged, and Who is this for Who is speaking in connection with the telephone. One year later, David Crystal explicitly considered the variety "distinctive as a dialect, not just as an accent" (1995: 327), again regarding certain grammatical features as characteristic of Estuary English, among them the most probably American-influenced omission of -ly adverbial endings as in your're turning it too slow, non-standard prepositional uses, and even the Cockney generalization of third person singular as in I gets out of the car as well as frequent confrontational question tags and an occasional innit for isn't it in jocular speech, with a possible move towards final standardization (ibid.). However, in spite of a considerable amount of lexicological and grammatical evidence, the linguistic identity of the variant continued to be discussed largely as a concept of pronunciation by Wells, who conceived it as a phonetic variant being "associated with standard grammar and usage" (1997: 1).

\section{Reactions and prospects}

Although the fashionable variant became relatively widespread and influential, its success story was at no time complete. While a possible move towards a "future classless society" was, after Crystal (1995: 3), envisioned by newspaper commentators in connection with the spread of the variant in the early nineties and aimed for even by former Prime Minister John Major, there was abundant upper (middle)-class aversion to the accent's lower-class stigmatized features. Since the 1980s, the variant had been given wide newspaper coverage, in editorials, articles and readers' letters, with a considerable amount of argument on the "errors" of elision and on the explosive issues of T-glottalling and -deletion threatening to "defile" the language "for the sake of fashion" 
(from The Sunday Express 1984, quoted in Mugglestone 1991: 330), and the Secretary of State for Education was taking sides with those defying the "erosion of the language" (cf. Bex 1994: 2, Coggle 1994: 1). Safeguarding the "standards" and the "purity" of the language, Estuary English was referred to as "slob speak" and "slack-mouthed patois" (Coggle ibid.), as "horrifying”, "slack-jawed”, "limp” and "flaccid", and the "all-pervading virus of 'London lad' speak" (cf. Kerswill 2001: 7). Even the BBC had to take its sentence with a listener stating: "We are plagued with idiots on radio and television who speak English like the dregs of humanity" (quoted by Maidment 1994: 7). In spite of its spread in all kinds of occupations and professions, among upperand middle-class young people and allegedly even among the younger members of the Royal Family, a stereotype assumed that "Estuary English mark[ed] its speakers as members of the lower strata of British society" (Coggle 1993: 85) and conservative speakers felt the standard language to be "usurped by the usage of people who are NOT OUR CLASS” (Maidment 1994: 7). In John Honey's traditionally middleclass view, the "deep unease" caused by this development was calling for a way of "bringing this new tendency in spoken standard English under control", be it by "a newly founded Academy or its unofficial equivalent” (1997: 168).

A completely different kind of aversion to Estuary English sprang from a Northern rejection of excessive Southern accent dominance arising from too much Cockney in England. Trudgill (1990: 14) suggested geographical borders to the acceptability of the fashion, referring to the "skilled practitioners of Cockey-style conversations", who might be valued as "amusing and interesting" in London, but were perceived in neighbouring East Anglia as being "arrogant and dominating". According to Marks (1999: 1), many Liverpudlians were pained by the prospect of becoming a linguistic "footnote", as Estuary had increased among Merseysiders and also among young Scousers under twentyfive, now saying fink for Northern dialectal tink (thing) and bruvver for traditional brudder (brother). Further to the South-West, in Winchester and Southampton, r-lessness in car and warm had come to be favoured by the young, providing a fashionable urban image in contrast to older and rural speech (cf. Coggle 1993: 27), an image of the ordinary and less privileged, of toughness and efficiency as represented by the fashionably popular speech of London. However, when the accent was 
claimed by Northerners to be "difficult to understand" (McKay 1996: 1), this disqualification will have had less to do with actual intelligibility problems than with Northern aversion to the accent's connotations of Southern power and superiority. In the same way as earlier speculations on a possible replacement of the RP model by Estuary have found their limitations in the rejection of its decidedly popular character by many of the conservatively educated classes, the traditional accent loyalty in the North has so far prevented a victory of the Southern variant over regional speech.

Regarding the future of Estuary English, Rosewarne, in his early speculations on the accent's linguistic influence, had seen it "in a strong position to exert influence on the pronunciation of the future" (1984: 1 ), considering it "the new model for general imitation" among the most influential sections of the young generation and expecting it to become the pronunciation of the majority of speakers, the strongest native influence on RP and, probably, "the RP of the future" (ibid. 3). Spreading socially and geographically, the mixed variant might, in Coggle's view, "well become the broad meeting place, the common ground for a coming together in British society" (1993: 87) and, therefore, deserve to be labelled "The new Standard English", as actually happened in the subtitle of his 1993 book (Do You Speak Estuary? The new Standard English). Two years later, David Crystal confirmed the claim of Estuary to the "phonetic throne", in his vision of a future "gradual replacement of one kind of standard by another" (i. e. of RP by Estuary; 1995: 365). In his less radical prediction of a further spread of Estuary English, Rosewarne, about the same time, envisioned a future majority of speakers in England - with the exception of the highest and lowest socioeconomic groups - being either Estuary speakers or using "certain features of Estuary English in combination with elements of whatever their regional speech might be" (1994: 8). Although it seems doubtful that either current RP or the Northern Standards might be willing to retreat in favour of the successful merger from the South East, the trendy accent may, for a certain time, remain a particularly influential variant of the spoken language, at least as far as England is concerned. 


\section{Conclusion}

Being part of the universal impact of London-based tendencies on current English English, various shades and degrees of mixing between Cockney and RP against the popular background of the Thames Estuary as well as additional influence from abroad account for the variant's particular sociolinguistic complexity and for its considerable acceptability among the young of different geographical regions and social backgrounds. It may well be assumed that, due to its successful sociophonetic convergence, Estuary English may well function as a new kind of Southern regional standard of wider social validity while, in connection with the cosmopolitan image of the Capital, some of its most characteristic features may continue to be adopted and incorporated in the speech of the younger generation everywhere in England. Its term, however, may turn out to be a passing fashion, together with its further spread and diffusion into ongoing southernization processes and become finally neutralized, as time goes by.

\section{References}

\section{Books and contributions}

Coggle, Paul 1993: Do You Speak Estuary? London.

Cruttenden, Alan 1994: Gimson's Pronunciation of English. London.

Crystal, David (Ed.) 1995: The Cambridge Encyclopedia of the English Language. Cambridge.

Foulkes, Paul; Docherty, G. J. 1999: Urban Voices. Accent Studies in the British Isles. London.

Honey, John 1997: Language is Power. London.

Kerswill, Paul 2001: Dialect levelling and received pronunciation. In Pilvy Rajame (Ed.), British Studies in the New Millennium: Challenge of the Grassroots. Tartu, Estonia. Cf. website.

Longman Dictionary of English Language and Culture. Editor-in-chief Della Summers. London 1992.

Maidment, J. A.: Estuary English: Hybrid or Hype? Paper pres. at $4^{\text {th }}$ New Zealand Conference on Language and Society 1994; cf. website.

Mc Crum, Robert, Cran, William; Mac Neil, Robert 1992: The Story of English. London.

Mugglestone, Lynda 1995: 'Talking Proper'. The Rise of Accent as Social Symbol. Oxford, New York.

Rosewarne, David 1994: Estuary English - tomorrow’s RP? English Today 37. Estuary English (1984). See below 2. 
186

Schoenberger, F. 2001: Update on English Language and Culture. Estuary English In PADL-Post-Graduate Services to TEFL Teachers (undated); cf. website.

Trudgill, Peter: The Dialects of England. Oxford, Cambridge/ Mass. 1994 (1 $1^{\text {st }}$ publ. 1990).

Watt, Dominic; Milroy, Lesley 1999: Patterns of variation and change in three Newcastle vowels: is this dialect levelling? In Paul Foulkes; G.J. Docherty, Urban Voices. Accent Studies in the British Isles. London.

Wells, J. C. 1982: Accents of English. Parts 1 and 2. Cambridge, London, New York.

Wells, J. C.: The Cocknification of RP. In G. Melchers, N.-L. Johannesson (Eds.), Nonstandard varieties of language. Papers from the Stockholm Symposium (1991), Stockholm 1994 (1); cf. website.

Wells, J. C.: Recommendations for standardized phonetics of Estuary English.1994 (2). Website.

Wells, J. C.: Transcribing Estuary English: a discussion document. In Speech Hearing and Language: UCL Work in Progress, Vol. 8, 1994 (3); cf. website.

Wells, J. C.: What is Estuary English? In English Teaching Professional 1997; cf. website.

Wells, J. C.: Pinning down Estuary English. Abstract for a lecture given in Lund, Sweden, April 1998; cf. website.

\section{Articles in newspapers and periodicals}

Ascherson, Neil: Britain's crumbling ruling class is losing the accent of authority. The Independent on Sunday, 7 Aug. 1994; cf. website.

Bex, Tony: Estuary English. The Guardian (Education section), 6 Sept. 1994; cf. website.

Coggle, Paul: A gobstopper in the glottals. The Times Educational Supplement, 11 April 1994; cf. website.

Forbes, Cosmo: Tony puts the accent on being popular. The Express, 5 June1998.

Mc Kay, Sinclair: I Believe in Estuary English. The Daily Telegraph, 16 Nov.1996; cf.website.

Morris, John: The accent that dare not speak its name. The Independent on Saturday, 21 March 1999; cf. website.

Rosewarne, David: Estuary English. The Times Educational Supplement, 19 Oct. 1984.

\section{Radio stations}

BBC 1

BBC World Service London

Capital Radio London

Hallam FM Sheffield 